\title{
Meramu Materi Pembelajaran Sejarah Berlandaskan Analisis Historical Thinking
}

\author{
Hera Hastuti, Iqrima Basri, Zafri \\ herahastuti@fis.unp.ac.id, iqriimbas05@gmail.com, zafriajo@fis.unp.ac.id \\ Universitas Negeri Padang
}

\begin{abstract}
Historians or history teacher always say that studying history is important. However, these words seem to have lost their meaning in history class, because in reality history learning is trapped in the stigma of rote learning that asks for years, places, names of characters and events. Basically history has its own approach in teaching it to students, namely historical thinking. Historical thinking includes the ability to understand chronology, think causality, interpretation, think three dimensions of time, and the ability to explore the value or moral dimension of each event. The obstacle faced so far is that teachers do not yet have the ability to formulate history learning materials that are taught to students at the stage of historical thinking. By using the bibliographic method, this research formulates the stages of historical thought, which are then set forth in one example of a historical event. So that this research does not only produce stages in the analysis of historical thought, but also historical materials mixed in each stage of his thinking.
\end{abstract}

Keywords: Historical Thinking, Chronology, Causality, Interpretation, Three Dimensions of Time.

\begin{abstract}
Abstrak
Sejarawan ataupun pendidik sejarah selalu mengatakan bahwa pembelajaran sejarah itu penting. Namun, kata-kata ini seolah kehilangan makna dalam kelas sejarah, karena pada kenyataannya pembelajaran sejarah terperangkap dalam stigma pembelajaran hafalan yang menanyakan tentang tahun, tempat, nama tokoh dan peristiwa. Pada dasarnya sejarah memiliki pendekatan tersendiri dalam membelajarkannya kepada peserta didik, yaitu berpikir sejarah atau yang lebih dikenal dengan historical thinking. Historical Thinking mencakup kemampuan berpikir kronologis, berpikir kausalitas, interpretasi, berpikir tiga dimensi waktu, dan kemampuan dalam menggali nilai-nilai atau dimensi moral dari setiap peristiwa. Kendala yang dihadapi selama ini yaitu, pendidik belum memiliki kemampuan dalam merumuskan materi pembelajaran sejarah yang diajarkan kepada peserta didik dalam tahapan historical thinking. Menggunakan metode kepustakaan, kajian ini merumuskan tahapan berpikir sejarah, yang kemudian dituangkan dalam salah satu contoh peristiwa sejarah. Sehingga penelitian ini tidak hanya menghasilkan tahapan-tahapan dalam analisis historical thinking, tetapi juga materi sejarah yang diramu dalam setiap tahapan berpikir tersebut.
\end{abstract}

Kata Kunci: Historical Thinking, Kronologis, Kausalitas, Interpretasi, Tiga Dimensi Waktu. 


\section{Pendahuluan}

Pembelajaran sejarah berfungsi untuk menyadarkan peserta didik tentang proses perubahan dan perkembangan masyarakat. Berbagai peristiwa dengan berbagai versi menjadikan mereka mampu bersikap kritis serta semakin arif dalam bertindak dan berbuat, sehingga kesadaran sejarah dalam menemukan, memahami, dan menjelaskan jati diri bangsa di masa lalu, masa kini, dan masa depan dapat berjalan secara baik. Senada dengan yang disampaikan oleh Abdullah \& Surjamihardjo (1985) menyebutkan bahwa sejarah bukan semata-mata suatu gambaran mengenai masa lampau, tetapi sebagai suatu cermin masa depan. Penjelasan-penjelasan sejarah mampu menjadi ukuran bertindak dalam kehidupan, seperti yang diungkapkan oleh Dilthey; life only takes on a measure of transparency in the light of historical reason (Kartodirdjo, 1959). Sejarah bukan saja berkisah tentang peristiwa tetapi juga mengulas persepsi dan pandangan masyarakat (Adam, 2005). Berbagai perubahan dan keberlanjutan yang disajikan dalam penjelasan sejarah akan memberikan gambaran tentang kehidupan dan menunjukkan nilai-nilai penting yang selayaknya menjadi ukuran dalam bertindak.

Banks (2004) menyatakan daya kritis dan kecerdasan siswa dalam memahami peristiwa masa lampau membuat mereka menjadi arif karena mengambil pelajaran dari pengalaman orang-orang dimasa lalu untuk masa yang akan datang. Seluruh kemampuan yang harus dimiliki oleh peserta didik tersebut tentunya bisa diperoleh dengan bimbingan seorang pendidik yang paham bagaimana sejarah seharusnya diajarkan. Analisis peristiwa sejarah yang terjadi dimasa lalu dibutuhkan ketajaman interpretasi yang lebih dari sekedar kemampuan 'mencari informasi di dalam teks' yang mendominasi kegiatan belajar di sekolah. Teori belajar yang kompleks sekalipun tidak pernah membahas tentang proses atau langkah-langkah yang digunakan untuk membentuk interpretasi dari teks tertulis yang rumit.

Ketajaman interpretasi peserta didik hanya dapat diperoleh ketika mereka memiliki kemampuan Historical Thinking. Wineburg (2006) menegaskan bahwa historical thinking atau berpikir historis merupakan jalan untuk memetakan masa depan dengan mengajarkan masa lalu. Intinya, masa lalu dapat bermakna jika ia digunakan untuk kehidupan masa kini, dan masa depan, disinilah sejarah sebagai tiga dimensi waktu diterapkan.

Kemampuan Historical Thinking mencakup kemampuan dalam menginterpretasi peristiwa sejarah secara keseluruhan secara teoritis, kemampuan kausalitas atau menganalisis hubungan sebab-akibat. Historical thinking juga menyangkut kemampuan dalam memaknai peristiwa sejarah atau menangkap dimensi moral dari setiap peristiwa, dan kemampuan tiga dimensi waktu, yakni menganalisis masa lalu, untuk kehidupan hari ini dan menafsirkan masa depan (Peter Seixas \& Peck, 2004; Winerburg, 2006). Ulasan ini kembali menegaskan pentingnya kemampuan historical thinking yang harus dimiliki peserta didik. Kemampuan ini tidak bisa dimiliki oleh peserta didik secara otodidak, harus ada latihan terus menerus yang dilakukan oleh pendidik dalam kelas. 
Lalu, apa peran pendidikan sejarah dalam memperbaiki kemampuan berpikir sejarah peserta didik? Bell dan David F. McCollum (dalam Winerburg, 2006) menjelaskan beberapa hal yang dapat dilakukan diantaranya; mengajak peserta didik memahami peristiwa masa sekarang berdasarkan masa lalu, melakukan kritik sumber terhadap segala hal yang berhubungan dengan sumber sejarah, menuntun anak melakukan perenungan tajam untuk menjawab pertanyan-pertanyaan yang menuntut pemikiran yang dalam tentang situasi dan peristiwa sejarah tertentu, dan tentu saja melatih anak menjawab pertanyaan berdasarkan fakta dan peristiwa sejarah.

Akan tetapi pada prakteknya banyak terjadi penyimpangan-penyimpangan pembelajaran sejarah yang terjadi di sekolah, bahkan di perguruan tinggi. Dimana pembelajaran lebih terpaku pada jumlah materi yang diajarkan ke peserta didik (memenuhi target kurikulum). Padahal, semakin padat materi, semakin kurang gerak kreativitas dalam penyampaian dan pembahasannya dalam kelas. Diskusi kelompok, tanya jawab, penyampaian materi dengan metode ceramah, merupakan pemandangan umum yang biasa kita saksikan dalam kelas-kelas sejarah.

Hakikatnya, permasalahan ini tidak hanya ada di sekolah-sekolah menengah, tetapi juga di perguruan tinggi. Misalnya, beberapa pendidik di Jurusan Sejarah Universitas Negeri Padang masih terpaku pada ulasan materi sejarah dan mendiskusikan apa yang ada dalam teks, tanpa memberi makna pada materi tersebut untuk kehidupan keseharian peserta didik, apalagi untuk kehidupan mendatang. Contohnya saat membahas tentang Sejarah Eropa, yang didiskusikan atau yang ditanyakan ke peserta didik yaitu tentang karakteristik abad pertengahan di Eropa, atau nama kelompok yang berhasil menguasai dan menyatukan kawasan kerajaan Romawi. Kemudian pembahasan lain seperti pembahasan tentang Sejarah Asia Timur, yang ditanyakan ke peserta didik yakni tentang proses modernisasi dan imperialisme yang dialami oleh Jepang, atau meminta anak menjelaskan tentang politik luar negeri Cina dengan Amerika.

Hal ini tentu saja berdampak pada kemampuan peserta didik yang hanya berada pada tingkat mengubah kata-kata, bukan melakukan analisis, menginterpretasi dan mengulas teks. Penyajian teks bagi mereka terkait erat dengan isi; mereka membaca untuk mendapat informasi. Kebanyakan peserta didik mengira bahwa jika mereka paham semua kata dan dapat mengubah susunan isi teks mereka telah sukses membaca teks bersangkutan. Tidak hanya peserta didik, bahkan pendidikan menganut keyakinan seperti itu.

Pembelajaran sejarah minim interpretasi apalagi analisis tiga dimensi waktu. Jika pun ada ditemukan analisis kausalitas pada soal, hanya sekedar "ingatan" karena sudah ada uraiannya dalam teks atau buku. Sebuah ironi memang, Sejarah tetap berada di kemampuannya, yang menciptakan gap atau jarak yang begitu lebar dengan kehidupan manusia hari ini. Maka tidaklah mengherankan Sejarah sebagai sebuah pembelajaran kehilangan makna.

Berbagai persoalan yang dihadapi dalam pembelajaran sejarah ini, baik di sekolah menengah maupun di perguruan tinggi, tentunya memiliki banyak solusi yang dapat dilakukan. Mulai dari metode, model, media, dan strategi pembelajaran 
yang telah tersedia, hakikatnya bisa diterapkan dalam pembelajaran sejarah. Namun, apabila ditinjau lebih mendalam, persoalan utama yang harus segera dibenahi yaitu materi pembelajaran sejarah itu sendiri. Materi sejarah yang tersedia saat ini di berbagai sumber belajar lebih banyak mengulas fakta-fakta dan peristiwa, minim interpretasi apalagi berpikir tiga dimensi waktu, apalagi nilai-nilai. Sehingga tujuan utama dari artikel ini yakni mengulas tahap demi tahap materi sejarah yang 'biasa' yang terdapat pada umumnya sumber belajar, dengan landasan berpikir sejarah atau historical thinking. Tahapan-tahapan yang dilakukan dalam analisis materi disesuaikan dengan tahapan berpikir sejarah, mulai dari jabaran tentang fakta, berpikir kronologis, kausalitas atau analisis sebab dan akibat dari suatu peristiwa, kemudian menginterpretasikan peristiwa tersebut berdasarkan fakta yang sahih, melakukan analisis tiga dimensi waktu, dan tentu saja menguraikan nilai-nilai kesejarahan yang dapat diambil dari rangkaian peristiwa-peristiwa tersebut.

\section{Metode Penelitian}

Penelitian ini berlandaskan pada studi kepustakaan atau yang sering disebut sebagai riset kepustakaan (Library Research) dengan menggunakan metode dokumentasi, yang dianalisis secara kritis. Metode ini digunakan untuk analisis mendalam dari sudut pandang para ahli pendidikan dan ahli sejarah mengenai historical thinking, kemudian meramu hasil pemikiran sejarawan tersebut dalam pembelajaran sejarah yang dapat diterapkan pada ulasan setiap materi berupa peristiwa sejarah.

Menurut Mestika Zed (2004) studi kepustakaan merupakan pemanfaatan segala sumber kepustakaan untuk memperoleh data penelitian. Riset kepustakaan dibatasi pada bahan-bahan yang ada di perpustakaan yang tentunya berkaitan dengan penelitian tanpa perlu melakukan riset lapangan. Intinya, studi kepustakaan adalah serangkaian kegiatan yang berkaitan dengan pengumpulan data pustaka, membaca dan mencatat serta mengolah bahan penelitian. Sugiyono (2013)Sugiyono (2013) menambahkan bahwa riset kepustakaan merupakan penelitian yang mengkaji secara teoritis setiap fenomena. Pengumpulan data tidak hanya sebatas pada sumber yang ada 'di ruang' perpustakaan, tetapi juga data yang diperoleh dari berita dan artikel pada portal berita online yang terpercaya, dan tentu saja juga menggunakan jurnal publikasi yang relevan dengan penelitian. Kemudian data yang sudah terkumpul dianalisis menggunakan konten analisis atau analisis isi, yang menekankan pada pembahasan mendalam tentang informasi yang terdapat pada literatur atau sumber (Kripendorf dalam Subrayogo, 2001).

Tahapan yang digunakan pada penelitian ini mengikuti langkah-langkah kepustakaan yang dijabarkan oleh Mestika Zed (2004); Pertama, dengan menyiapkan perlengkapan yang dibutuhkan dalam riset. Perlengkapan yang dimaksud di sini seperti referensi-referensi yang dibutuhkan sehubungan dengan topic penelitian, baik tentang materi sejarah, pembelajaran sejarah, dan tentu saja tentang berpikir sejarah. Sumber-sumber ini diperoleh dari buku-buku dan artikel jurnal, baik nasional maupun 
internasional. Kedua, menyusun bibliografi kerja, membaca dan membuat catatan penelitian. Pada tahapan ini selain memilah-milah sumber dengan berpedoman pada kritik sumber, menilai 'kelayakan' referensi tidak hanya dari segi konten, tetapi juga dari penulisnya. Kemudian dilanjutkan dengan membaca dengan seksama dan membuat catatan-catatan penting yang berhubungan dengan isu yang diangkatkan. Terakhir dilakukan analisis datanya dengan analisis-sintesis dan interpretasi, sehubungan dengan data yang telah diperoleh, sebelum penulisan dilakukan dengan mengacu pada penulisan ilmiah.

\section{Hasil dan Pembahasan Penelitian}

\section{Tahapan Analisis Historical Thinking}

Bicara tentang sejarah, ada tiga komponen penting yang saling terkait; Pertama, sejarah adalah semua peristiwa atau kejadian masa lalu yang benar-benar terjadi (history is actuality) dan memiliki keterkaitan dengan masa kini. Kedua, sejarah merupakan metode yang digunakan oleh sejarawan untuk merekonstruksi masa lalu. Sejarah dalam hal ini dimaksudkan sebagai ilmu yang bertugas menyelidiki perubahan-perubahan tersebut. Ketiga, sejarah yaitu pendapat tertulis sejarawan tentang masa lalu, biasanya dikenal dengan istilah interpretasi sejarah (Kuntowijoyo, 1995; Sjamsuddin, 2012; Suhartono., 2010). Menganalisis dari ketiga komponen ini diperoleh satu kesimpulan bahwa sejarah merupakan peristiwa masa lalu yang memiliki karakteristik perubahan dan mempengaruhi kehidupan manusia hari ini yang ditulis oleh sejarawan. Tulisan-tulisan sejarawan ini lah yang kemudian kembali dirumuskan dalam pembelajaran sejarah yang kemudian diajarkan di sekolah dan perguruan tinggi.

Sejarah sebagai pembelajaran memiliki misi dan tugas-tugas yang sangat penting. Seperti yang dikemukakan oleh Aldrich (2005), the three duties of the historian of education; the duty to the people of the past, the duty to our own generation, and the duty to search after the truth. Sejarah dapat memberikan gambaran, tindakan maupun perbuatan manusia dengan segala perubahannya. Perubahan inilah yang dikaji oleh sejarah. Abdullah \& Surjamihardjo (1985) menyebutkan bahwa sejarah bukan sematamata suatu gambaran mengenai masa lampau, tetapi sebagai suatu cermin masa depan. Penjelasan-penjelasan sejarah mampu menjadi ukuran bertindak dalam kehidupan, seperti yang diungkapkan oleh Dilthey; life only takes on a measure of transparency in the light of historical reason (Kartodirdjo, 1959). Sejarah bukan saja berkisah tentang peristiwa tetapi juga mengulas persepsi dan pandangan masyarakat (Adam, 2005).

Menurut Hunt (2006) ada sembilan tujuan dari pembelajaran sejarah, seperti, memahami masa kini dalam konteks masa lalu, membangkitkan minat tentang masa lalu, identitas kebangsaan, pemahaman tentang akar dan warisan budaya, kontribusi terhadap negara dan kebudayaan, melatih berpikir keilmuan sejarah, pengenalan terhadap metodologi sejarah, kebutuhan kurikulum, dan terakhir sebagai persiapan 
untuk kehidupan peserta didik di masa depan. Dari pendapat Hunt ini dapat dirumuskan tiga tujuan utama dari pembelajaran sejarah yakni kecakapan atau kemampuan akademik, kesadaran sejarah, dan nasionalisme. Kecakapan akademik untuk melatih kemampuan berpikir, khususnya berpikir sejarah atau historical thinking.

Keterampilan berpikir historis merupakan langkah-langkah yang sistematik yang harus dilakukan untuk memecahkan permasalahan dalam rangka menghasilkan produk sejarah (Foster, S.J. \& Padgett, 1999). Kemudian P Seixas \& Peck (2004) menyatakan "historical thinking: historical cognition as specified by as the process by which students employ procedural knowledge and disciplined inquiry." Lebih lanjut Winerburg (2006) mengungkapkan, 'berpikir sejarah mengharuskan kita mempertemukan dua pandangan yang saling bertentangan; pertama, cara berpikir yang kita gunakan sekarang ini adalah warisan yang tidak dapat disingkirkan, dan, kedua jika kita tidak berusaha menyingkirkan warisan itu mau tidak mau kita harus menggunakan "presentisme", yaitu melihat masa lalu dengan kacamata masa kini'. Intinya Wineburg dengan tegas menyatakan bahwa terdapat kesinambungan masa lalu yang membentuk masa kini, dan adanya perubahan unsur-unsur, nilai dan tatanan masyarakat sebagai bentuk dari reinterpretasi terhadap perubahan zaman.

Setiap perubahan terjadi dalam waktu. Hidup manusia senantiasa dikuasai oleh waktu. Keberadaan manusia di dunia senantiasa memiliki saat awal dan saat akhir. Pada jangka waktu antara awal dan akhir keberadaannya itulah manusia mengarungi masa hidupnya dengan menyejarah. Pada menyejarah itulah terjadi proses dialektika antara perubahan dan keberlanjutan (Daliman, 2012). Daliman juga menegaskan bahwa, 'konsep perubahan merupakan konsep yang paradoksal'. Perubahan pada dasarnya memadukan pengertian mengenai suatu perbedaan dan sesuatu yang tetap sama. Mempertemukan keduanya akan mampu membangkitkan kesadaran akan waktu, dan menghadirkannya dalam pembelajaran sejarah akan dapat menjadi refleksi bagi tindakan kita di masa yang akan datang.

Kemampuan Historical Thinking mencakup kemampuan berpikir kritis dalam menginterpretasi peristiwa sejarah secara keseluruhan secara teoritis, kemampuan kausalitas atau menganalisis hubungan sebab-akibat. Mestika Zed (2018) menjabarkan bahwa konsep berpikir sejarah atau historical thinking merupakan bagian dari upaya untuk meningkatkan semangat berpikir kritis dalam sejarah, sehingga pembelajaran sejarah semakin dekat dengan semangat ilmiah.

Sam Wineburg (2010) menegaskan bahwa "Berpikir sejarah mengharuskan kita mempertemukan dua pandangan yang saling bertentangan; pertama, cara berpikir yang kita gunakan selama ini adalah warisan yang tidak dapat disingkirkan, dan kedua jika kita tidak berusaha menyingkirkan warisan itu, mau tidak mau kita harus menggunakan presentism yang membuat buntu pikiran itu, yang melihat masa lalu dengan kacamata sekarang". Memaknai pernyataan Sam Wineburg di atas, bahwa setiap masa itu akan berbeda genrenya, atau yang lebih dikenal dengan Zeitgeist-nya. Masa lalu tidak akan pernah bisa disamaratakan dengan masa sekarang. Jiwa zaman yang berbeda akan menjadikan peristiwa yang terjadi di kedua masa ini sangat 
berbeda pemaknaannya, tidak bisa disamakan sekalipun peristiwa yang terjadi adalah sama.

Banyak ahli sejarah yang membahas tentang historical thinking, mulai dari ahli sejarah dari luar seperti Sam Wineburg, hingga sejarawan tanah air seperti Mestika Zed. Dari pemikiran sejarawan tersebut, dapat disimpulkan beberapa komponen yang membangun tingkat berpikir historical thinking mencakup; 1) Berpikir kronologis, 2) berpikir kausalitas, 3) interpretasi, 4) Berpikir tiga dimensi waktu, 5) keterampilan mengambil dimensi moral dari setiap peristiwa sejarah. Seluruh komponen tersebut saling terkait satu sama lain untuk membangun historical thinking.

Berpikir kronologis menempati tahapan pertama dari historical thinking bukannya tanpa dasar. Berpikir kronologis sangat berkaitan dengan waktu, tentu saja, karena sejarah adalah ilmu yang bergelut dalam pusaran waktu. Sehingga berpikir kronologis membangun tahap awal dari pengertian atas waktu (masa lalu, sekarang dan masa datang). Kronologis mengidentifikasi urutan waktu atas setiap kejadian, mengukur waktu kalender, menginterpretasikan dan menyusun garis waktu, serta menjelaskan konsep kesinambungan sejarah dan perubahannya.

Menurut Drake (2007) berpikir kronologis merupakan "jantung-nya" dalam berpikir kesejarahan. Berpikir kronologis menjadi dasar bagi pemahaman kesejarahan di mana jika dasar pemahaman sejarah tersebut sudah baik, maka akan membantu memahami sejarah di tingkat berpikir kesejarahan yang lebih tinggi. Berpikir kronologis mencakup kemampuan mengidentifikasi waktu masa lalu, masa sekarang dan masa yang akan datang serta struktur waktu dalam peristiwa sejarah yang kemudian disusun secara kronologis. Susunan temporal tersebut membantu dalam mengukur dan memperhitungkan waktu dalam satu periodisasi sejarah sehingga mampu merekonstruksi peristiwa sejarah pada satu waktu dengan baik (Dara, Mala Citra, \& Setiawati, 2017).

Tahapan berikutnya yakni berpikir kausalitas atau dikenal juga dengan berpikir sebab dan akibat. Bahwa setiap peristiwa pasti disebabkan oleh peristiwa sebelumnya dan bisa menjadi penyebab atas peristiwa selanjutnya. Filsuf kerap menegaskan bahwa tidak ada satupun didunia ini yang terjadi secara tunggal, semuanya memiliki sebab dan bersebab (Salehnur, 2014). Meskipun merupakan konsep umum, kausalitas merupakan tahapan kedua dari Historical Thinking skill. Peristiwa sejarah yang telah diurutkan secara kronologis kemudian dianalisis menggunakan pisau analisis kausalitas. Menggali kenapa sebuah peristiwa terjadi dan apa akibat yang ditimbulkannya.

Pentingnya kausalitas dalam sejarah, ditegaskan juga oleh Mestika Zed (2018) bahwa kausalitas telah membangun kekhasan dalam sejarah, karena tanpa adanya konsep "sebab", sejarah akan kehilangan ciri keilmiahannya. Hukum kausalitas dalam sejarah selalu berlangsung dalam lintas waktu. Namun bukan berarti semua rentetan tindakan atau kejadian berlangsung dalam rangkaian sebab-akibat, melainkan dalam bentuk hubungan "korelasi" atau koeksistensi (berlangsung bersamaan).

Tahap ketiga dari historical thinking yaitu interpretasi. Interpretasi adalah tafsiran, penjelasan, makna, arti, kesan, pendapat, atau pandangan teoritis terhadap 
suatu objek yang dihasilkan dari pemikiran mendalam dan sangat dipengaruhi oleh latar belakang orang yang melakukan interpretasi. Kamus Besar Bahasa Indonesia (KBBI) mendefinisikan interpretasi sebagai pemberian kesan, tafsiran, pendapat, atau pandangan teoretis terhadap sesuatu hal atau objek. Interpretasi merupakan konsep atau istilah yang universal, hampir seluruh ilmu memiliki interpretasi masing-masing. Sejarah merupakan salah satu ilmu yang sangat berkaitan dengan interpretasi, artinya bahwa sejarah itu sendiri merupakan hasil dari penafsiran para sejarawan terhadap suatu peristiwa. Misalnya, ketika Raja Kerajaan Kutai, Mulawarman memberikan hadiah sebanyak 20.000 ekor sapi kepada para Brahmana (Hastuti, Hera., Zafri \& Asri, 2019), maka dapat diinterpretasikan bahwa Mulawarman merupakan raja yang dermawan dan sangat menghormati kaum Brahmana. Interpretasi juga bisa dari jumlah sapi yang luar biasa banyaknya, hal ini mengindikasikan bahwa saat itu pada akhir abad ke-4 M, sudah ada peternakan sapi atau sudah ada profesi sebagai pengembala sapi, karena sangat tidak mungkin bahwa sapi-sapi tersebut ditangkap dari sapi liar yang ada di hutan mengingat jumlahnya yang begitu banyak.

Berikutnya yakni berpikir tiga dimensi waktu. Dimensi waktu sering dikaitkan dengan sejarah, hal ini tak lain karena sejarah sendiri berkecimpung dalam ranah waktu. Sejarah mempunyai tiga dimensi waktu, yaitu masa lampau sebagai objek studinya dan sebagai pembanding peristiwa masa kini dan juga masa yang akan datang sebagai akibatnya (Haif, 2016).

Dimensi waktu dalam sejarah sering disebut dengan istilah Change over time, yang artinya perubahan dalam lintas waktu. Sejarah adalah ilmu tentang waktu, dan setiap waktu punya perubahan dan perbedaan tersendiri, namun sekalipun begitu, setiap perubahan yang terjadi di waktu yang berbeda tersebut memiliki benang merah atau keterkaitan satu sama lainnya (Zed, 2018). Itulah mengapa dimensi waktu dalam sejarah ada tiga, yakni masa lalu, masa kini dan masa yang akan datang. Dimensi waktu dalam sejarah menunjukkan betapa pentingnya waktu, karena mampu mengaitkan tiga masa yang berbeda, dan sejatinya masa lalu itu tidak pernah jauh dari kita.

Mencari makna atau nilai yang terkandung dalam rangkaian peristiwa sejarah merupakan tahapan akhir dari berpikir sejarah atau historical thinking. Sejarah tidak hanya 'sekedar' menceritakan kembali peristiwa yang telah terjadi atau peristiwaperistiwa masa lampau yang sudah terjadi berabad-abad yang lalu. Namun lebih kompleks dari itu, bahwa sejarah merupakan ilmu yang mampu menghidupkan kembali ruh-ruh masa lampau yang juga berguna bagi masa kini dan masa mendatang dengan cara memetik makna yang ada di setiap peristiwanya. Dari ungkapan tersebut diketahui bahwa sejarah adalah ilmu yang sarat dengan makna dan nilai. Makna dalam artian bahwa setiap peristiwa yang dijadikan sejarah ada peristiwa yang memiliki arti penting bagi khalayak banyak.

Ankersmit (1987) mengatakan bahwa makna sejarah dapat memiliki empat macam penafsiran. Pertama, makna sejarah sebagai tujuan terakhir dalam perjalanan proses sejarah. Kedua, arti proses sejarah. Ketiga, tujuan dan gunanya pengkajian sejarah. Keempat, arti pengkajian sejarah. Artinya bahwa makna sejarah menjadi point 
utama atau tujuan yang paling utama dalam proses membelajarkan sejarah, di mana peserta didik mampu memahami maksud dan nilai yang tersirat di dalam setiap peristiwa sejarah, untuk itulah sejarah harus dipelajari secara keseluruhan, bukan potongan-potongan.

\section{Meramu Materi Pembelajaran Sejarah Berlandaskan Historical Thinking}

Setelah merumuskan tahapan historical thinking hasil analisis dari berbagai ahli atau sejarawan. Maka dalam proses pembelajaran sejarah, tahapan tersebut dapat diaplikasikan atau diterapkan pada seluruh materi pembelajaran sejarah yang membahas tentang peristiwa. Mulai dari peristiwa-peristiwa yang terjadi semenjak zaman prasejarah hingga kontemporer saat ini. Penegasannya bagaimana mengolah materi sejarah yang ada di masa lampau agar berguna untuk kehidupan hari ini dan masa yang akan datang dan tentu saja nilai-nilai yang dapat diambil dari keseluruhan peristiwa tersebut. Salah satu contoh peristiwa yang dapat diulas menggunakan tahapan historical thinking mulai dari kronologis hingga nilai-nilai yakni pembahasan tentang kerajaan-kerajaan di Nusantara, misalnya Kerajaan Sriwijaya. Fakta sejarah yang menjadi landasan analisis yaitu Kerajaan Sriwijaya yang berpusat di Palembang mencapai puncak kejayaan pada masa pemerintahan Raja Balaputradewa pada abad VIII M. Lebih lengkap aplikasi analisis historical thinking terdapat pada tabel berikut (Hastuti, Hera., Zafri \& Asri, 2019),

\begin{tabular}{|c|c|}
\hline $\begin{array}{l}\text { Komponen } \\
\text { Historical } \\
\text { Thinking }\end{array}$ & Aplikasi \\
\hline \multirow[t]{3}{*}{ Kronologis } & $\begin{array}{l}\text { Kronologis erat kaitan dengan urutan waktu, urutan waktu kerajaan } \\
\text { atau peradaban identik dengan; lahir, berkembang, kejayaan, } \\
\text { kemunduran, dan kehancuran. }\end{array}$ \\
\hline & $\begin{array}{l}\text { Kronologis kejayaan Kerajaan Sriwijaya dimulai sejak berkembang } \\
\text { sekitar abad VII M dibawah pemerintahan Raja Dharmasetu yang } \\
\text { mampu menjadikan Sriwijaya sebagai pusat perdagangan di Asia. } \\
\text { Kemapanan perekonomian kerajaan membuat Sriwijaya semakin } \\
\text { meluaskan kekuasaannya pada dekade-dekade berikutnya, sehingga } \\
\text { kekuasaannya sampai ke indocina. }\end{array}$ \\
\hline & $\begin{array}{l}\text { Kerajaan Sriwijaya mencapai puncak kejayaannya pada masa } \\
\text { pemerintahan Balaputradewa pada abad VIII M. }\end{array}$ \\
\hline \multirow[t]{4}{*}{ Kausalitas } & $\begin{array}{l}\text { Kausalitas yaitu hubungan sebab - akibat suatu peristiwa. Kejayaan } \\
\text { Kerajaan Sriwijaya di masa pemerintahan Balaputradewa abad VIII M } \\
\text { disebabkan oleh beberapa faktor yaitu; }\end{array}$ \\
\hline & $\begin{array}{l}\text { 1. Semakin majunya Sriwijaya sebagai pusat perdagangan di Asia, } \\
\text { karena terjaminnya keamanan para pedagang di wilayah Sriwijaya. }\end{array}$ \\
\hline & $\begin{array}{l}\text { 2. Sebagai kerajaan maritim Sriwijaya memiliki angkatan laut yang } \\
\text { kuat yang mampu mengamankan perbatasan wilayah-wilayah } \\
\text { Sriwijaya dari musuh. }\end{array}$ \\
\hline & $\begin{array}{l}\text { 3. Banyaknya kerajaan-kerajaan kecil yang meminta perlindungan ke } \\
\text { Sriwijaya dan mengakui Sriwijaya sebagai kerajaan induk. }\end{array}$ \\
\hline
\end{tabular}




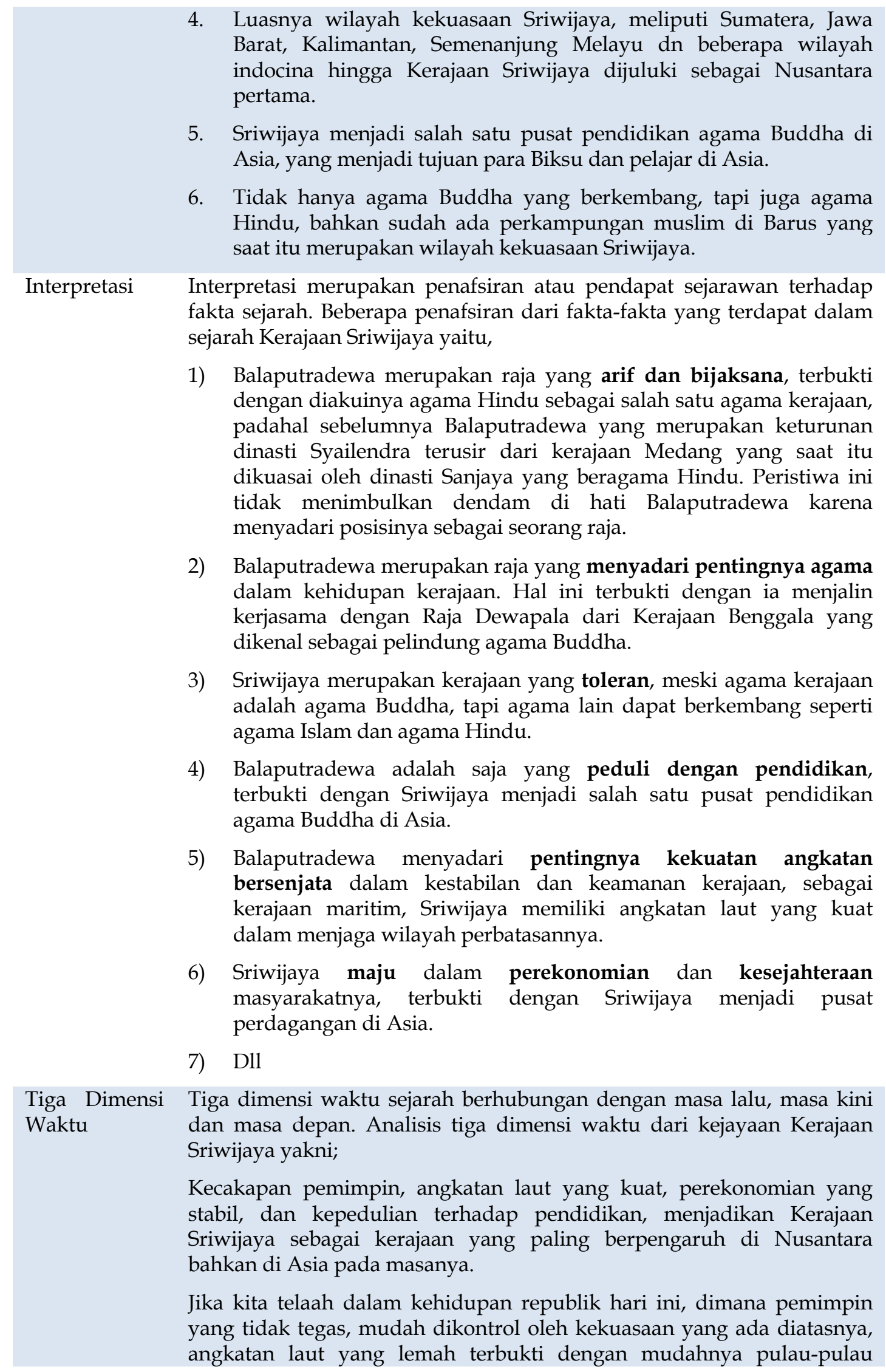




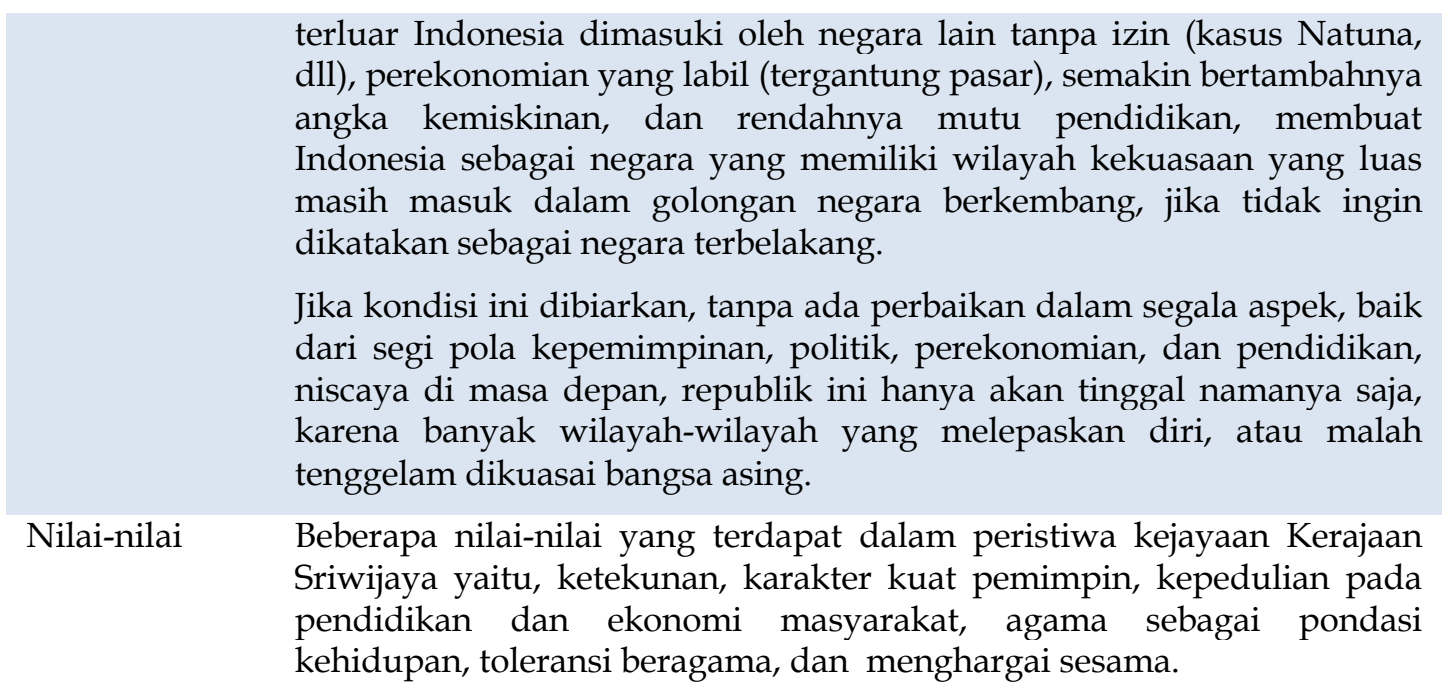

Tabel 1. Tahapan aplikasi historical thinking dalam materi pembelajaran sejarah

Ulasan sejarah Kerajaan Sriwijaya dengan menggunakan analisis historical thinking memberi pengalaman baru bagi peserta didik dalam belajar sejarah. Sejarah tidak melulu bicara tahun, tokoh, tempat, atau fakta-fakta yang sudah ada selama ini. Sudah saatnya sejarah diajarkan dengan kekiniaan, tidak hanya tentang metode, model, ataupun media, tetapi lebih pada penekanan dan ulasan materinya dibawa ke zaman sekarang, dan historical thinking memungkinkan semua itu terjadi. Benarlah apa yang dikatakan oleh Winerburg (2006) "Charting the future of teaching the past" bahwa historical thinking atau berpikir historis merupakan jalan untuk memetakan masa depan dengan mengajarkan masa lalu. Intinya, masa lalu dapat bermakna jika ia digunakan untuk kehidupan masa kini, dan masa depan.

Sebagai 'aliran baru' dalam gaya penulisan sejarah, tentu saja dibutuhkan latihan-latihan yang dilakukan secara terus menerus agar historical thinking ini dapat diterapkan dengan maksimal di kelas-kelas sejarah. Akan tetapi, meramu materi pembelajaran sejarah berlandaskan analisis historical thinking tidak akan bisa dilakukan jika guru atau pendidik tidak memahami peristiwa sejarah, atau minim pengetahuan tentang sejarah. Tetap saja pengetahuan pendidik tentang materi sejarah dan kemampuan dalam membelajarkannya merupakan tonggak awal historical thinking dapat dilakukan. Kecakapan pendidik dalam mengaplikasikan historical thinking dalam setiap materi sejarah berupa peristiwa mampu membangun konstruksi berpikir siswa bahwa kehidupan manusia hari ini dipengaruhi oleh sejarah yang terjadi dimasa lalu. Perubahan dimasa depan dapat tercapai jika generasi muda peduli dengan kehidupan bangsa, serta memperbaiki kesalahan-kesalahan yang terjadi hari ini, dan ini lah goals utama dari belajar sejarah.

\section{Simpulan}


Hera Hastuti, Iqrima Basri, Zafri

Meramu Materi Pembelajaran Sejarah Berlandaskan Analisis Historical Thinking

Hakikatnya historical thinking bukanlah hal baru, namun yang merumuskannya dalam pembelajaran sejarah dengan langsung mengemasnya dalam ulasan materi sejarah, khususnya materi yang bersifat peristiwa belum pernah ada dilakukan. Bila Pun ada hanyalah sepenggal-sepenggal tanpa ulasan utuh dalam tahapan berpikir sejarah. Meramu materi sejarah dengan landasan historical thinking tentu saja memberi angin segar pada pembelajaran sejarah yang selama ini terkenal menjemukan oleh peserta didik. Bila pendidik sudah memiliki kemampuan menganalisis materi sejarah berlandaskan historical thinking, maka apapun metode, pendekatan, model, strategi, dan media yang digunakan dalam pembelajaran sejarah di kelas, akan mencapai hasil yang maksimal. Meski tidak dapat dipungkiri, kajian teoritis ini membutuhkan penelitian lebih lanjut, baik dalam bentuk penelitian pengembangan, maupun eksperimen. Pengembangan meliputi pembuatan bahan ajar yang berbasis historical thinking yang dapat menjadi panduan pendidik saat mengajar, dan eksperimen untuk menganalisis pengaruhnya dalam proses dan hasil pembelajaran sejarah baik di sekolah menengah, maupun di perguruan tinggi.

\section{Daftar Pustaka}

Abdullah, T., \& Surjamihardjo, A. (1985). Arah, Gejala dan Perspektif Studi Sejarah Indonesia, dalam Ilmu Sejarah dan Historiografi, Arah dan Perspektif. In Gramedia, Jakarta. Gramedia.

Adam, A. W. (2005). "Sejarah Politik dan Politik Sejarah" dalam Frederick,William H. dan Soeri Soeroto (edt.). Pemahaman Sejarah Indonesia: sebelum dan sesudah revolusi. Pustaka LP3ES.

Aldrich, R. (2005). Lessons from history of education: the selected works of Richard Aldrich. Routledge.

Ankersmit, F. . (1987). Refleksi tentang Sejarah; Pendapat-pendapat Modern tentang Filsafat Sejarah (terjemahan Dick Hartoko dari Denken over geschiedenis; een overzicht van moderne geschiedfilosofosche opvattingen). Gramedia.

Banks, J. A. (2004). Teaching for Social Justice, Diversity and Citizenship in a global world. The Educational Forum, 68, 286-298.

Daliman, A. (2012). Penghantar Filsafat Sejarah. Penerbit Ombak.

Dara, Mala Citra, \& Setiawati, E. (2017). Pengaruh penggunaan media timeline terhadap kemampuan berpikir kronologis pembelajaran sejarah di sman 2 
metro. Jurnal Historia, 1.

Drake, S. M. (2007). Creating Standards-Based Integrated Curriculum: Aligning

Curriculum, Content, Assessment, and Instruction. ERIC.

Foster, S.J. \& Padgett, C. . (1999). Authentic historical inquiry in the social studies classroom. The Clearing House, 72(357).

Haif, A. (2016). Hadist Sebagai Sumber Sejarah. Jurnal Rihlah, 4(1).

Hastuti, Hera., Zafri \& Asri, Z. (2019). Nusantara Zaman Pengaruh Hindu dan Buddha. Manggu.

Hunt, M. (2006). A practical guide to teaching history in the secondary school. Routledge.

Kartodirdjo, S. (1959). The Philosophy of History in Our Time. Doubleday Anchor Books Doubleday \& Company, Inc.

Kuntowijoyo, D. R. (1995). Pengantar ilmu sejarah. Bentang Pustaka.

Salehnur. (2014). Kausalitas. Jurnal Ushuluddin, 22(2).

Seixas, P, \& Peck, C. (2004). Teaching historical thinking. Dalam A. Sears \& I. Wright (Eds). Challenges and Prospects for Canadian Social Studies. Vancouver: Pacific Educational Press. Halaman.

Seixas, Peter, \& Peck, C. (2004). Teaching historical thinking. Pacific Educational Press.

Sjamsuddin, H. (2012). Metodologi Sejarah. Penerbit Ombak.

Subrayogo, I. (2001). Metodologi Penelitian Sosial-Agama. Bandung: Remaja Rosdakarya.

Sugiyono, P. D. (2013). Metode Penelitian Pendidikan Pendekatan Kuantitatif Kualitatif, dan R \& D. In Pendekatan Kuantitatif. Alfabeta.

Suhartono. (2010). Teori \& metodologi sejarah. Graha Ilmu.

Wineburg, S. (2006). Historical Thinking and other Unnatural Acts Charting the Future of Teaching the Past. Yayasan Obor Indonesia. Terjemahan Yayasan Obor Indonesia.

Wineburg, S. (2010). Historical Thinking and Other Unnatural Acts. Phi Delta Kappan, 92(4).

Winerburg, S. (2006). Berpikir historis: Memetakan masa depan, mengajarkan masa lalu. (Terjemahan Masri Maris). Yayasan Obor Indonesia.

Zed, M. (2004). Metode Penelitian Kepustakaan. Yayasan Pustaka Obor Indonesia.

Zed, M. (2018). Tentang Konsep Berpikir Historisvol. Lensa Budaya: Jurnal Ilmiah Ilmu-Ilmu Budaya, 13(1). 